\title{
Household Solid Waste Composition Focusing on Hazardous Waste
}

\author{
Dana Adamcová ${ }^{\text {, Magdalena Daria Vaverková }}{ }^{*}$, \\ Bohdan Stejskal ${ }^{1}$, Eliška Břoušková ${ }^{2}$ \\ ${ }^{1}$ Department of Applied and Landscape Ecology, Faculty of Agronomy, Mendel University in Brno, \\ Zemědělská 1, 61300 Brno, Czech Republic \\ ${ }^{2}$ Department of Morphology, Physiology and Animal Genetics, Faculty of Agronomy, Mendel University in Brno, \\ Zemědělská 1, 61300 Brno, Czech Republic
}

Received: 23 May 2015

Accepted: 7 December 2015

\begin{abstract}
Internationally, almost $70 \%$ of municipal solid waste is disposed of in landfills and may contain hazardous substances in the form of paints, vehicle maintenance products, mercury-containing waste, pharmaceuticals, batteries, and many other products. The present study has attempted to address the problem of hazardous waste in the context of municipal solid waste generated in a typical urban scenario. The study was conducted in year 2013. The sorting of the waste was performed manually. Determining the quantity of hazardous and potentially hazardous ingredients in household waste was carried out on the 10 samples of the collection from the cities of Kroměřǐz (City 1) and Brno (City 2). Results revealed that the share of household hazardous waste found in Kuchyňky landfill was $2.047 \%$ of the total municipal solid waste stream. The results are based on actual measurements, where the percentage of household hazardous waste has been estimated based on sampling in a municipal landfill.
\end{abstract}

Keywords: landfill, waste characterization, waste composition

\section{Introduction}

Since the beginning of civilization we have produced solid waste. During the earliest periods, solid waste was conveniently and unobtrusively disposed of in large open land spaces, as the density of the population was low. Today, however, rapid urbanization, increasing population, and developing living standards have created large amounts of solid waste all over the world [1-5]. Municipal solid wastes (MSW) coming from activities carried out in homes, places of public and private service,

*e-mail: magda.vaverkova@uake.cz buildings, and commercial and service establishments form an important portion of the solid waste problem [6]. Management and treatment of these wastes is required in order to prevent serious environmental health risks [6]. The disposal of waste in landfills is the most used and cheapest of all waste management techniques [7].

Household waste - any waste produced from a domestic source - represents more than two-thirds of the MSW stream [8]. Internationally, almost $70 \%$ of MSW is disposed of in landfills [8, 9]. MSW contains hazardous substances in the form of paints, vehicle maintenance products, mercury-containing waste, pharmaceuticals, batteries, and many other products [10]. To achieve maximum protection of the environment against the 
hazards associated with open dumping, all potential hazards must be identified and assessed properly [7].

Unlike the waste streams originating from industrial sources, hazardous substances in household waste are not strictly controlled under hazardous waste regulations such as the U.S. Resource Conservation and Recovery Act 1976 (RCRA) and the European Hazardous Waste Directive 91/689/EEC [11]. As such, household hazardous waste (HHW) is disposed of in landfills along with general household waste (HW). The amounts and significance of this disposal are poorly understood. Generally, it is assumed that amounts are small and therefore risks of disposal are negligible. Nevertheless, disposal information is lacking or, at best, unreliable and ambiguous. Changes to legislation requiring the separate disposal of MSW, industrial, and other wastes raises the importance of the hazardous element contained in MSW [12].

As concern about chemicals in household products increases [13], the potential consequences to the environment from the disposal of HHW are also moving to the fore. It is therefore important to ascertain the level of risk inherent in the disposal of HHW to landfill, as permitted by current legislation [12].

\section{Hazardous Waste in Municipal Solid Waste}

HW may be generated from residential and nonresidential sources, hence the need to study the amount and categories of this type of waste. This information is fundamental to the design of appropriate management strategies, to avoid current mixing and co-disposal with non-hazardous waste. However, the variety of products and the heterogeneity of sources make the quantification of this type of waste difficult. Thus, the characterization of containers, packaging, and wrapping materials of products that contained hazardous products by composition might be used as an indicator to estimate the amount of HW mixed and disposed of with the MSW. There are items used regularly in houses, trade centers, administrative centers, and institutions, such as cleaning products, selfcare products, medicine, home-care products, automotive maintenance products, electronic equipment, and general maintenance products for machinery. The aforementioned types of products are formulated with substances that, by themselves or when reacting with others, produce additional compounds that when attaining certain concentration levels might be capable of causing severe environmental and public health damage [14].

One of the problems with daily household products is that their chemical formulation is largely unknown, both quantitatively and qualitatively. It is reasonable to expect that the chemical brew produced in a landfill matrix is altogether difficult to stabilize and able to produce substances with stronger damaging effects [14].

There is a wide-reaching discussion about the name and characteristics that should be applied to categorize HHW. The clarification of this topic is essential to determine suitable solid waste management strategies.
When discussing the term "contaminant," Rushbrook and Pugh [15] stated that contaminant waste includes a broad range of products considered hazardous for a variety of factors, one of them being the toxicity grade, where the cumulative effects of sub-products are exerted upon living organisms.

The present study has attempted to address this concern in the context of MSW generated in a typical urban scenario. The primary objective was to develop the profile of specific compounds and to quantify the predominant hazardous pollutants possible in MSW. For this purpose, both fresh MSW and that mined from an open landfill in Kuchyňky (Czech Republic) were extracted and screened for hazardous compounds. Results of this study could be useful in the decisions of appropriate solid waste disposal methods and modifying present methods.

\section{Material and Methods}

\section{Location: Basic Characteristic of the Kuchyňky Landfill}

The Kuchyňky landfill (Fig. 1) is situated in a triangular space delimited by main roads connecting the villages of Zdounky, Nětčice, and Troubky-Zdislavice at a distance of ca. 1,800 m NNW of the church in Zdounky, $750 \mathrm{~m} \mathrm{NNW}$ of the built-up area limits in Zdounky, and $450 \mathrm{~m} \mathrm{SW}$ of the boundary line of Nětčice. In terms of maintenance, the landfill is classified in the S-category (other waste, sub-category S-OO3). The designed area of the landfill is $70,700 \mathrm{~m}^{2}$ in five stages with a total volume of $907,000 \mathrm{~m}^{3}$, i.e., ca. $1,000,00010^{3} \mathrm{~kg}$ of waste. Up to now, Stage I of $19,200 \mathrm{~m}^{2}$ has been constructed together with parts of Stage II $\left(5,500 \mathrm{~m}^{2}\right)$ and Stage III $\left(7,500 \mathrm{~m}^{3}\right)$. Planned service life of the facility is up to year 2018.

The facility receives waste (category of other waste) from a catchment area with a population of ca. 75,000 residents. The annually deposited amount of waste is ca. $40,00010^{3} \mathrm{~kg}$, of which $50 \%$ are from the communal sphere. The approved landfill sector for waste of subcategory S-OO1 has not yet been opened. The sector will be intended for the disposal of waste (category of other waste) with the low content of organic biologically degradable substances. A sector of the landfill will be intended largely for the disposal of asbestos-containing wastes, gypsum-based waste, stabilized waste, waste with high sulphur content, and waste with increased metals content. Waste with the substantial content of organic biologically degradable substances must not be stored in that sector [16].

\section{Sorting the Waste}

The present study was conducted between May 2013 and September 2013. Waste sorting was performed by a team of three. The crew was carefully introduced to the purpose and importance of the scientific work and each crew member was instructed regarding the sorting 

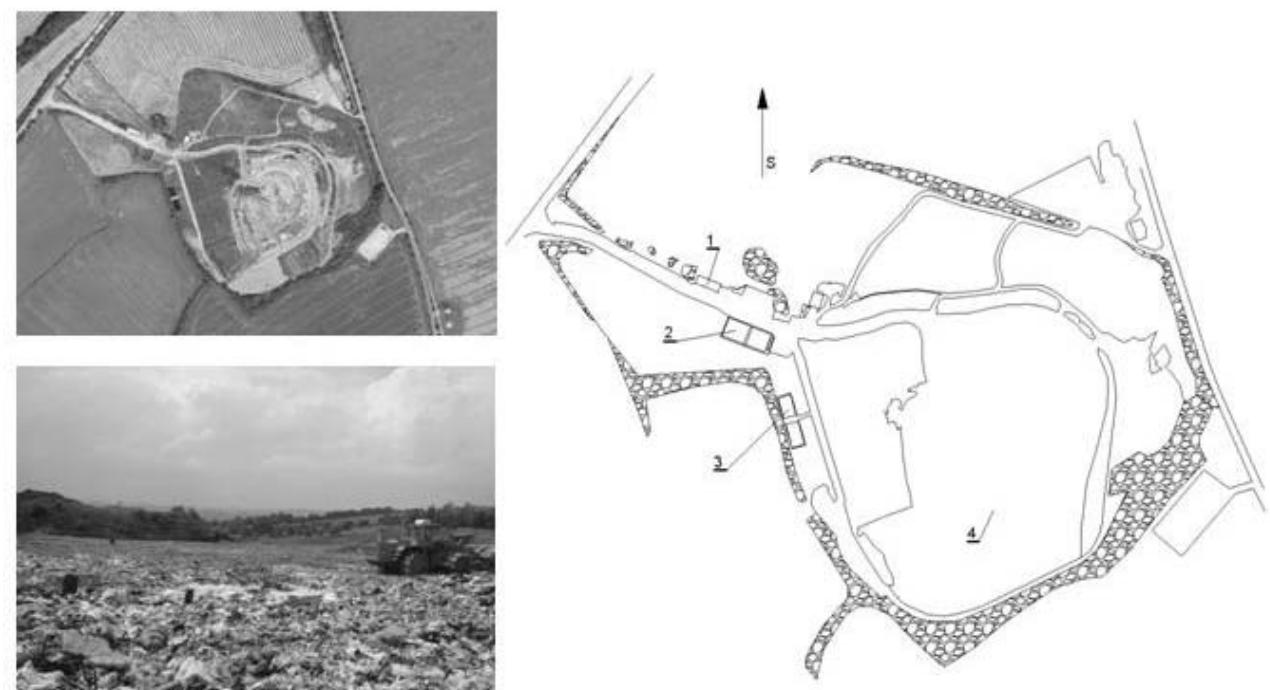

Fig. 1. Kuchyňky landfill and landfill surroundings.

procedures. Written sorting instructions were available. In case of doubt, the team leader was called to identify the correct type of fraction.

Determination of the quantity of hazardous and potentially hazardous ingredients in HW was always carried out on the 10 samples of the collection from City 1 and City 2 . The minimum required weight of one sample was $500 \mathrm{~kg}$ (the exact weight of the samples is listed in Table 1). The average weight of samples of MSW imported from City 1 amounted to $508.37 \mathrm{~kg}$, and from City $2507.78 \mathrm{~kg}$.

The individual samples were manually sorted according to dangerous waste potential HW. HW and sorted components were separately stored. Sorted components and the remaining municipal waste was weighed and the results recorded.

Table 1. Weights of the examined samples.

\begin{tabular}{|c|c|c|}
\hline Sample & MSW, City 1 $(\mathrm{kg})$ & MSW, City 2 $(\mathrm{kg})$ \\
\hline 1 & 514.78 & 517.43 \\
\hline 2 & 507.98 & 500.82 \\
\hline 3 & 512.29 & 511.20 \\
\hline 4 & 504.53 & 506.82 \\
\hline 5 & 502.10 & 515.57 \\
\hline 6 & 506.00 & 504.57 \\
\hline 7 & 508.40 & 510.70 \\
\hline 8 & 503.00 & 505.10 \\
\hline 9 & 506.20 & 505.30 \\
\hline 10 & 518.40 & 500.30 \\
\hline
\end{tabular}

\section{Results}

Charts were created based on the results. Fig. 2 compares the weights of the MSW $(\mathrm{kg})$ and mass of Total HW $(\mathrm{kg})$ for City 1 . In MSW total HW was identified ranging from $7.10-42.73 \mathrm{~kg}$ during the reported period.

City 1

$\square$ MSW $\square$ Total HW

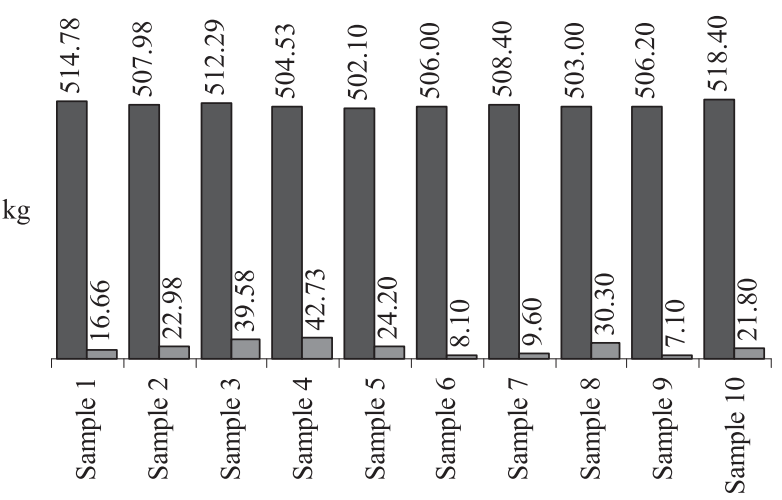

b)

City 1 - Total HW

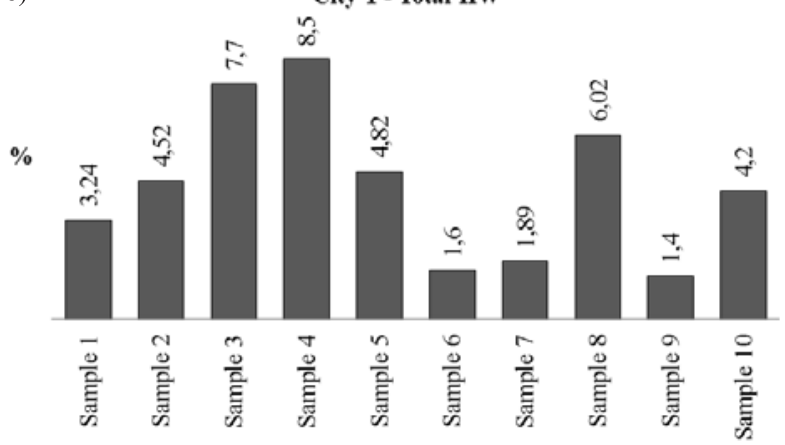

Fig. 2. Comparison of: a) MSW weights, total weight of HW, b) total weight of the HW expressed as a percentage for City 1 . 
a) City $2 \square$ MSW $\square$ Total HW

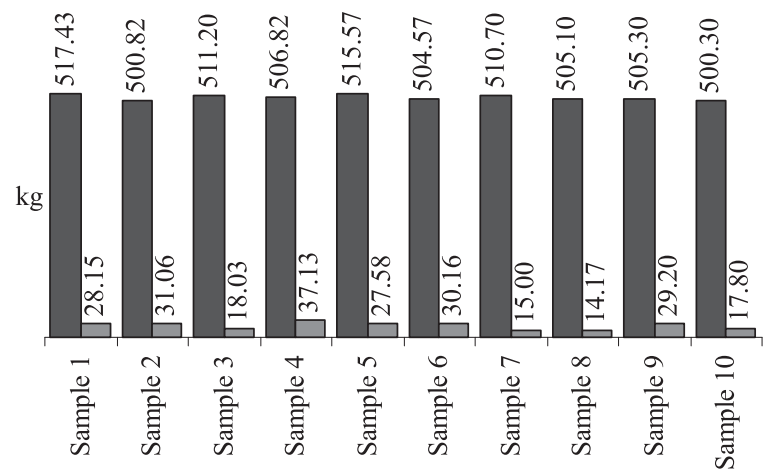

b)

City 2 - Total HW

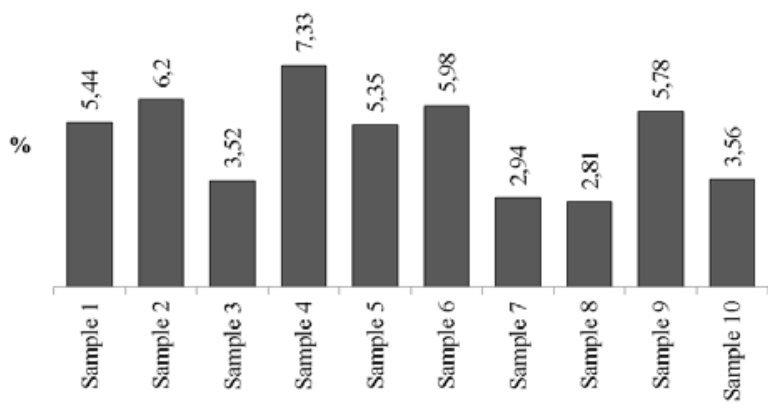

Fig. 3. Comparison of: a) MSW weights, total weight of HW, b) total weight of the HW expressed as a percentage for City 2 .

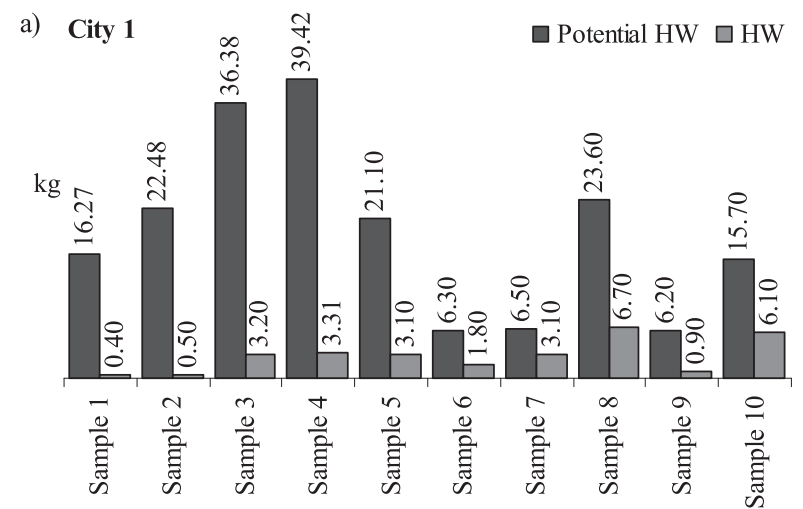

b)

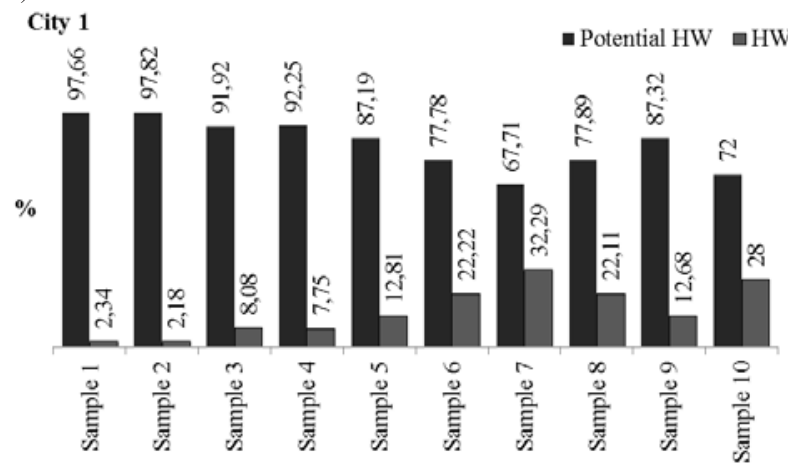

Fig. 4. The weight of: a) potential HW and HW, b) potential HW and HW expressed as a percentage for City 1.

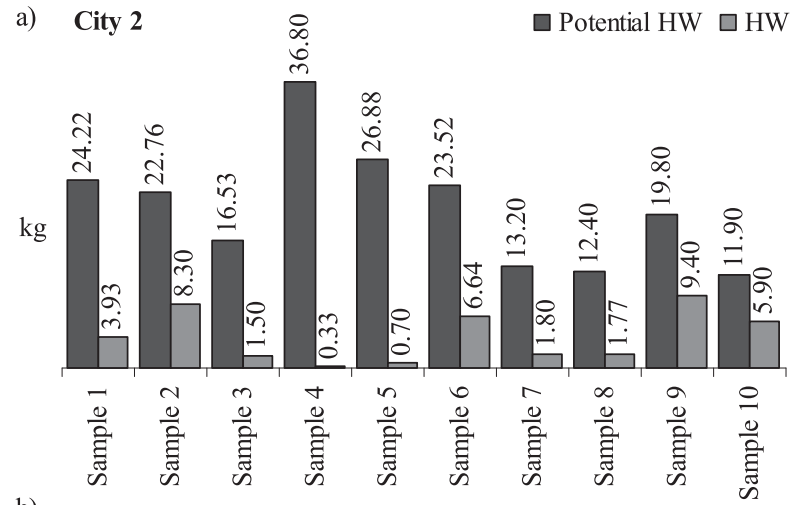

b)

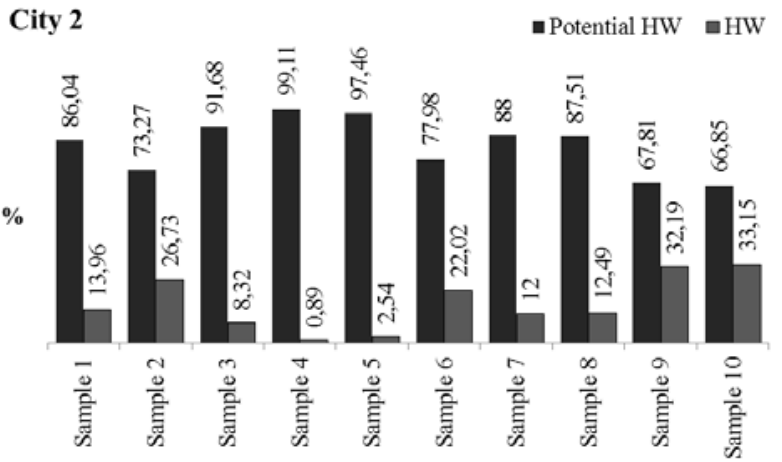

Fig. 5. The weight of: a) potential HW and HW, b) potential HW and HW expressed as a percentage for City 2.

Fig. 3 shows the comparison of the weight of MSW $(\mathrm{kg})$ and the total mass of the Total HW $(\mathrm{kg})$ for the City 2. In MSW we identified total HW ranging from 14.17$37.13 \mathrm{~kg}$ during the reporting period. City 2 levels reached higher total HW values than for City 1 .

Since in the course of research HW was identified, these wastes were divided into potential HW and HW. The weight of the waste for City 1 for each of the samples taken are listed in Fig. 4. The weight of potential HW in the period considered ranged $6.20-39.42 \mathrm{~kg}$. The weight of $\mathrm{HW}$ in the given period in the investigated samples ranged from $0.40-6.70 \mathrm{~kg}$.

The weight of potential HW and HW for City 2 for each of the samples taken are listed in Fig. 5. The weight

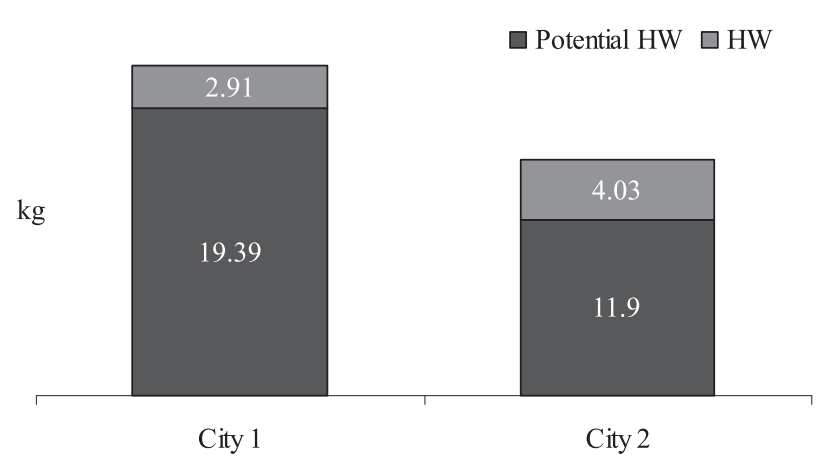

Fig. 6. Average values of Potential HW and HW in Cities 1 and 2. 
of potential HW in the period considered ranged from $6.20-39.42 \mathrm{~kg}$, and the weight of the HW ranged from $0.33-9.40 \mathrm{~kg}$.

Fig. 6 shows comparison of average stated values of Potential HW and HW in Cities 1 and 2. The MSW from City 1 included on average $3.8 \%$ potential HW and $0.57 \%$ HW. MSW in City 2 included potential HW of $2.34 \%$ and $0.79 \%$ HW. MSW from City 1 showed much higher values of potential HW (19.39 kg) than City 2, but in MSW from City 2 we found more HW (4.03 kg) than in City 1.

\section{Discussion}

Certain categories of HW are generated within households containing remnants of chemical fertilizers, pesticides, herbicides, cleaning products, etc., and are usually found in dump sites or even landfills [17]. A small portion (typically $1 \%$ by weight) is defined as HHW.

A review of 20 European counties, the USA (several states), Mexico, Canada, Greenland, Japan, India, Pakistan, Hong-Kong, and Nepal from 1992-2013 showed that the HHW quantities represent just a small percentage of overall MSW. In EU and the USA it is generally reported that the quantities of HHW arising represent $1 \%$ $\mathrm{w} / \mathrm{w}$ of municipal waste [18-20]. Inglezakis and Moustakas [21] collected 36 values of HHW percentage (w/w) in MSW [22-36]. The values are presented in Fig. 7. The average value is $0.90 \pm 0.39 \%$ (range $0.12-1.88$ ). As shown in Fig. 7, there is a scattering of values, but the majority is concentrated between 0.4 and $1.2 \%$. It is important to mention that these figures are rough approximations and are not based on actual measurements, with exceptions, as in the cases of Canada and Greece, where the percentage of HHW has been estimated based on sampling in a municipal landfill [21]. Other quantitative data present higher percentages of w/w content of HHW within MSW, exceeding $1 \%$ and even reaching $4 \%[21,37]$. Such variations can also take place within different areas of the same country and can be explained on the basis of different facts, including the different terms of HHW used and the different existing consumer patterns and ways of life around the world.

Our results revealed that the share of HHW found in Kuchyňky landfill was $2.047 \%$ of the total MSW stream. The results are based on actual measurements as in the cases of Canada and Greece [21], where the percentage of HHW has been estimated based on sampling in a municipal landfill. It is of crucial importance to be able to recognize solid waste composition (content of HW and Potential HW) when designing waste management and disposal strategies, and to decide about sanitary, public health, and environmental impact policies [37].

\section{Conclusions}

In many countries of the world MSW is landfilled without any sorting and, moreover, without proof of contents. Domestic waste contains certain percentage of dangerous substances that are potentially harmful, in amounts of $1 \%$ of MSW. There was a significant development when it comes to waste treatment and its regulation laid down by laws, such as, for example, setting objectives for recycling and preliminary treatment of biodegradable organic substances before adding it to the landfill, which now limit the speed of expansion of the landfill sites [38].

The present study was conducted in 2013. Determining the quantity of hazardous and potentially hazardous contents of household waste was always carried out on samples from Kroměříž (City 1) and Brno (City 2). In the MSW, despite considerable public awareness and

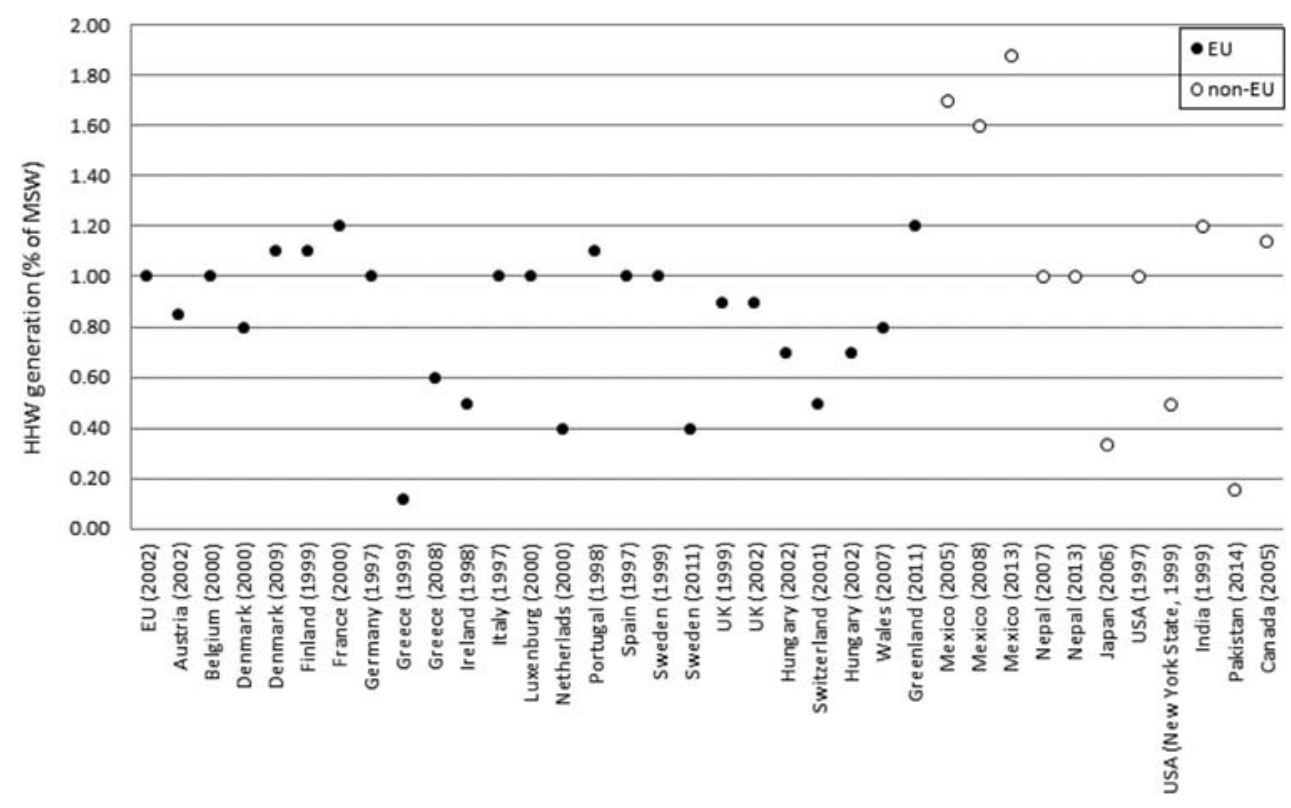

Fig. 7. HHW generation (\% of MSW) [19]. 
education of the population, we found and identified about $2.047 \%$ potential HHW.

The experiment was carried out in real conditions for the first time and its repetition is planned to be carried out again in the landfill in order to verify our initial experimental results.

\section{Acknowledgements}

This study was supported by the firm DEPOZ of the city of Zdounky. We would like to express our great appreciation to the management of Kuchyňky landfill. Namely, we are very grateful to Ing. Ivan Mohler and his colleagues for their assistance and their willingness to provide their time so generously.

This study was also supported by project Innovative 3D Platform for Recycling of Waste Electric and Electronics Devices (540527-LLP-2013-1-GR-LEONARDO-LMP).

\section{References}

1. HATTOPADHYAY S., DUTTA A., RAY S. Municipal Solid Waste Management in Kolkata, India - A Review. Waste Manage., 29 (4), 1449, 2009.

2. ELAGROUDY S., ELKADY T., GHOBRIAL F. Comparative Cost Benefit Analysis of Different Solid Waste Management Scenarios in Basrah, Iraq. J. Environ. Prot. 2, 555, 2011.

3. SAMAH M.A.A., MANAF L.A., AHSAN A, SULAIMAN W.N.A., AGAMUTHU P D'SILVA J.L. Household solid waste compositionin Balakong City, Malaysia: Trend and Management. Pol. J. Environ. Stud. 22 (6), 1807, 2013.

4. İSMAIL ÖZBAY. Evaluation of Municipal Solid Waste Management Practices for an Industrialized City. Pol. J. Environ. Stud. 24 (2), 637, 2015.

5. SHULAN ZHAO, LIAN DUO. Bioaccumulation of Cadium, Copper, Zinc, and Nickel by Weed Species from Municipal Solid Waste Compost. Pol. J. Environ. Stud. 24 (1), 413, 2015.

6. DOĞRUPARMAK Ş.Ç, YENICE M.K., DURMUŞOĞLU E., ÖZBAY B., ÖZ H.O. Solid Waste Characterization of Kocaeli. Polish J. of Environ. Stud. 20 (2), 479-484, 2011.

7. MAHMOOD K., BATOOL S.A., CHAUDHRY M.N., DAUD A. Evaluating Municipal Solid Waste Dumps Using Geographic Information System. Polish J. of Environ. Stud. 24 (2), 879, 2015.

8. OECD. Sector case studies: household energy and water consumption and waste generation: trends, environmental impacts and policy responses. (ENV/EPOC/WPNEP(2001)15/ FINAL). Organisation for Economic Cooperation and Development Environment Directorate 1999-2001 Programme on Sustainable Development. Paris, France7 OECD; 56, 2001.

9. ZACARIAS-FARAH A, GEYER-ALLELY E. Household consumption patterns in OECD countries: trends and figures. J. Clean. Prod. 11, 819, 2003.

10. SLACK R.J., GRONOW J.R., VOULVOULIS N. Hazardous components of household waste. Crit. Rev. Environ. Sci. Technol. 34, 419, 2004.

11. US Code. Solid Waste Disposal Act, as amended 1976 Resource Conservation and Recovery Act: Subtitle D (Solid
Waste Program). US Code (Acts of Congress) Title 42, Chapter 82, Subchapter I (Section 6901); 1976.

12. SLACKA R.J., GRONOWB J.R., VOULVOULIS N. Household hazardous waste in municipal landfills: contaminants in leachate. Sci. Total Environ. 337, 119, 2005.

13. BLUNDELL T., (Chairman). Chemicals in products: safeguarding the environment and human health. Royal Commission on Environmental Pollution. 24 ${ }^{\text {th }}$ Report, London, UK; 291, 2003.

14. DELGADO O.B., OJEDA-BENI'TEZ S., MA'RQUEZBENAVIDES L. Comparative analysis of hazardous household waste in two Mexican regions. Waste Manage. 27, 792, 2007.

15. RUSHBROOK P., PUGH M. Solid Waste Landfills in Middle and Lower Income Countries. A technical Guide to Planning, Design, and Operation. World Bank Technical Paper No. 426. Washington, DC, 274, 1999.

16. VAVERKOVÁ M.D., TOMAN F., KOTOVICOVÁ J. Research into the Occurrence of Some Plant Species as Indicators of Landfill Impact on the Environment Pol J. Environ. Stud. 21 (3), 755, 2012.

17. AL-KHATIB I.A., KONTOGIANNI S., ABU NABAA H., ALSHAMI N., AL-SARI' M.I. Public perception of hazardousness caused by current trends of municipal solid waste management. Waste Manage. 36, 323, 2015.

18. GENDEBIEN, A., LEAVENS, A., BLACKMORE, K., GODLEY, A., LEWIN, K., FRANKE, B., FRANKE, A Study on Hazardous Household Waste (HHW) with a Main Emphasis on Hazardous Household Chemicals (HHC). Final Report, European Commission, Directorate General Environment. European Commission, 2002.

19. NHHWF, National Household Hazardous Waste Forum. The Haz Guide 2008, UK, 2008.

20. USEPA. United States Environmental Protection Agency, Household Hazardous Waste Reduction, EPA-905-f-97e011, USA, 1997.

21. INGLEZAKIS V.J., MOUSTAKAS K. Household hazardous waste management: A review. J. Environ. Manage. 150, 310, 2015.

22. BERNSTAD, A., JANSEN, J.C., ASPEGREN, H. Propertyclose source separation of hazardous waste and waste electrical and electronic equipment e a Swedish case study. Waste Manage. 31, 536, 2011.

23. BURNLEY S.J., ELLIS J.C., FLOWERDEW R., POLL A.J., PROSSER H. Assessing the composition of municipal solid waste in Wales. Resour. Conserv. Recy. 49, 264, 2007.

24. CRD. Solid Waste Annual Report. Capital Regional District, Victoria, Canada, 2009.

25. DANGI M.B., PRETZ C.R., URYNOWICZ M.A., GEROW K.G., REDDY J.M. Municipal solid waste generation in Kathmandu. Nepal. J. Environ. Manage 92, 240. 2011.

26. GENDEBIEN A., LEAVENS K., GODLEY K. Study on hazardous household waste (HHW) with a main emphasis on hazardous household chemicals (HHC). In: Tenth International Waste Management and Landfill Symposium, Sardinia, 2005

27. EISTED R., CHRISTENSEN T.H. Characterization of household waste in Greenland. Waste Manage. 31, 1461, 2011.

28. JADOON A., BATOOL S.A., CHAUDHRY M.N. Assessment of factors affecting household solid waste generation and its composition in Gulberg Town, Lahore, Pakistan. J. Mater. Cycles Waste Manag. 16, 73, 2014.

29. LAKSHMIKANTH H., LAKSHMINARASIMAIAH N. Household hazardous waste generation-management. In: Proceedings of the International Conference on Sustainable 
Solid Waste Management, 5-7 September 2007, Chennai, India, 163, 2007.

30. LAMBETH. Management of Household Hazardous Waste, Waste Management Policy \& Procedure Document, London Borough of Lambeth, 2012

31. OJEDA-BENÍTEZ S., AGUILAR-VIRGEN Q., TABOADA-GONZÁLEZ P., CRUZ-SOTELO S.E. Household hazardous wastes as a potential source of pollution: a generation study. Waste Manage. Res. 31 (12), 1279, 2013.

32. OTONIEL B.D., MÁRQUEZ-BENAVIDES L., PINETTE G.F. Consumption patterns and household hazardous solid waste generation in an urban settlement in México. Waste Manage. 28, S2-S6, 2008.

33. PATAKI G.E., CAHILL J.P. Household Hazardous Waste Report 1988 through 1999 Program Review, New York State, Department of Environmental Conservation. Division of Solid \& Hazardous Materials, New York, USA, 2000.

34. RIBER C., PETERSEN C., CHRISTENSEN T.H. Chemical composition of material fractions in Danish household waste. Waste Manage. 29, 1251, 2009.

35. YASUDA K., TANAKA M. Report on hazardous household waste generation in Japan. Waste Manage. Res. 24, 397, 2006.

36. DELGADO O.B., OJEDA-BENITEZ S., MARQUEZBENAVIDES L., Comparative analysis of hazardous household waste in two Mexican regions. Waste Manage. 27, 792. 2007.

37. ROBINSON A., SEWELL G., DAMODARAN N., DAVID E., KALAS-ADAMS N. Landfills in developing countries and global warming. In: Proceedings Sardinia, Ninth International Waste Management and Landfill Symposium, 6-10 October 2003. S. Margherita di Pula, Cagliari, Italy, 2003.

38. BIALOWIEC A. Contemporary Problems of Management and Environmental Protection. „Some Aspects of Environmental Impact of Waste Dumps" 9, 2011. 
